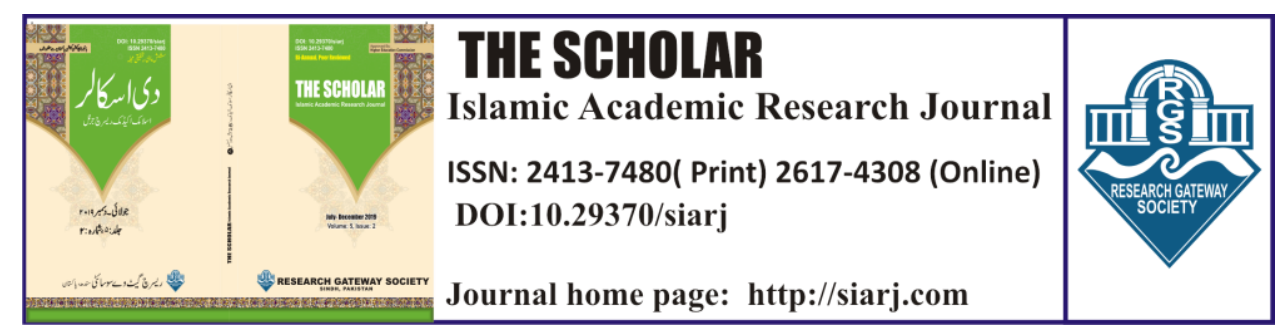

\title{
THE PREVALENCE OF SEXUAL ABUSE IN WOMEN (TYPES, CAUSES, EFFECTS) AND ITS REMEDIES IN ISLAM
}

\section{Shazia Bhutto \\ Ph.D. Scholar, Department of Comparative Religion and Islamic Culture \\ University of Sindh, Jamshoro, Pakistan. \\ Email : bhuttoshazia25@gmail.com}

\section{ORCID ID:}

https://orcid.org/0000-0002-9372-7975

To cite this article:

Bhutto, Shazia, and Bashir Ahmed Rind. "THE PREVALENCE OF SEXUAL ABUSE IN WOMEN (TYPES, CAUSES, EFFECTS) AND ITS REMEDIES IN ISLAM.” The Scholar-Islamic Academic Research Journal 5, No. 2 (November 16, 2019): 128-138. To link to this article: https://doi.org/10.29370/siarj/issue9ar13
2. Dr. Bashir Ahmed Rind

Associate Prof: Department of Comparative Religion and Islamic Culture University of Sindh, Jamshoro, Pakistan Email: bashir rind2006@yahoo.com

\section{ORCID ID:}

https://orcid.org/0000-0001-9781-1106

\begin{tabular}{|c|c|}
\hline Journal & $\begin{array}{l}\text { The Scholar Islamic Academic Research Journal } \\
\text { Vol. 5, No. } 2 \text { || July-December } 2019 \text { || P. 128-138 } \\
\text { Research Gateway Society }\end{array}$ \\
\hline DOI: & 10.29370/siari/issue9ar13 \\
\hline$\overline{\text { URL: }}$ & https://doi.org/10.29370/siari/issue9ar13 \\
\hline License: & Copyright c 2017 NC-SA 4.0 \\
\hline Journal homepage & www.siarj.com \\
\hline Published online: & $2019-16-12$ \\
\hline
\end{tabular}
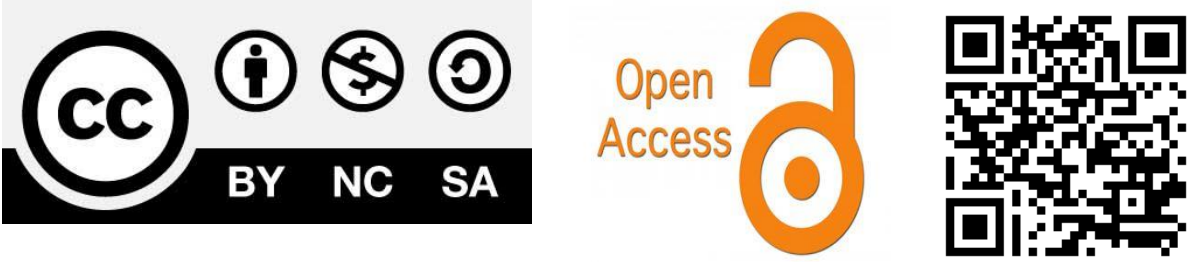
THE SCHOLAR (July - December 2019)

THE PREVALENCE OF SEXUAL ABUSE IN WOMEN (TYPES, CAUSES, EFFECTS) AND ITS REMEDIES IN ISLAM

Shazia Bhutto, Bashir Ahmed Rind

\section{ABSTRACT}

This research article deals with an important issue faced by women around the world, and it is sexual abuse or rape of women and its solution in the light of teachings of Islam. Islam forbids both fornication and sexual abuse or rape. The statistics shared in this article puts light on the worst condition faced by women as far as sexual abuse or rape is considered in different parts of the world and how Islam solves this very important issue.

KEYWORDS: Sexual Abuse, Rape, Gang Rape, Remedy, Islam

\section{INTRODUCTION:}

By sexual abuse it is meant that to have sexual intercourse with someone without consent or will of the person. That act could take place between husband and wife, friends and colleagues. The purpose of such act is not only to intimidate women but also their husbands and family members. Sexual Abuse of women during war is conducted to intimidate enemy. It is often taken that sexual abuse is conducted by unknown people, but from different surveys it is known that majority of women are sexually abused by known persons, some close relatives or persons they know well. Women of no race, country or nation is save from sexual abuse and it is an international problem. According to World Health Organization (WHO) 
One out of every five women has been sexually abused or someone has tried to abuse her. According to findings of WHO 44 percent of American women have been sexually abused once in their life or some one has tried to rape them. ${ }^{1}$

Sexual act without marriage contract is legal and lawful in America and European countries if both are in consent, but even after that freedom sexual abuse and rape is on high. Violation of women's rights is witnessed in America at greater level that claims to be champion of human rights. According to report of International Desk every week two thousand women are raped or sexually abused in America and ninety out of two thousand are murdered after rape or sexual abuse. ${ }^{2}$

Sexual assault and rape is more often seen on high during war time and natural calamities. Sussan Brown Miller whie commenting on History of Rape tells that as many as 20,000 Chinese women were raped and sexually abused in Nanxing as it was taken over by Japanese army. During the wars at Yougosilavia thousands of women were raped and according to an estimate 20 to 60 thousand women were raped or sexually abused. During the genocide of Rwanda as many as 10,000 women of Rwanda were sexually abused or raped and went through abortion. While 5600 bore children, they were sexually abused and raped for months, while of those women were kept by the fighters of Rwanda. ${ }^{3}$

\footnotetext{
${ }^{1}$ Ihsan Leghari, Āūrāt Jāy Khịilāf Ḍạ̣̣h Jo Khạạtmoo, (Karachi, Roshni Publishers) pg: 102

${ }^{2}$ A. Ghani , Abdul Ghani Farooq, Yeh Hāāi Māgrābī Ṭeḥ̣eeb,( Lahore, Kitab Sarai, 2009) pg: 112

${ }^{3}$ Ihsan Leghari, pg: 102
} 
This animal instinct of human being comes out when a weak person is before him, such beasts cross all limits of moral values and sexually abuse or rape women and consider it as an act of bravery. History has witnessed hundred thousands of such incidents, where innocent women became victims of such beastuallity.

\section{LITERATURE REVIEW:}

According to a report of American Medical Association seven lac women are sexually abused every year, likewise a woman is raped within every forty five seconds at an average. The President of Medical Association Loui Bristo presenting the details of report claimed that at an average the age of sixty six percent of women that are sexually abused or raped is under 18 years. While 75 percent of those girls are sexually abused or raped by their close relatives. ${ }^{4}$

Due to such increase in sexual abuse and rape the girls in United States are asked to carry weapons for their protection, but despite of that the situation is not under control. According to a survey from 1970 to 1972 some 37860 to 77763 cases of sexual abuse and rape were reported. According to another report 7 to 12 percent women claimed that they were sexually abused or raped at the age of $20 .^{5}$

In 1996, the Pentagon spending some .15 million dollars produced a documentary film to train its women staff to protect themselves from sexual abuse and rape, while it also formed a secret complaint cell in this

\footnotetext{
${ }^{4}$ Abdul Ghani Farooq pg: 112

5 Dr. Fazal Illahi, Amar bil-Ma'rauf Wa Nahi ul'Munkar Aur Khawateen Ki Zimidari, Karachi, 2001 Darul-Ishaat, pg: 111-112
} 
regard, as 90 percent of those women were asked for sexual favors during their recruitment, the complaint cell received 400 phone calls within in a week from such women who were sexually abused or raped. ${ }^{6}$

In Brazil certain rich people purchase young girls, these girls are sexually abused in gangs and are left alone, most of these incidents take place on weekends. (A Ghani, 2009, pg: 60). Some 1236 women were asked about sexual intercourse during a survey at London and the outcome was that every sixth woman was sexually abused and every fifth resisted against such abuse. $^{7}$

A survey report published in Medical Journal of Australia claimed that every fifth women in Australia has been sexually abused in her childhood, while only one out of ten cases is reported, the report also claimed that girls between age 8-10 are sexually abused or are under threat of abuse, majority of girls are those who don't have fathers. Australian medical students and lady doctors asked questions from 710 women and concluded that 41 percent of women were sexually abused by their relatives and eight percent were unknown persons. Six of ten women claimed that they were threatened before sexual abuse or rape in their childhood. ${ }^{8}$

According to Russian Interior Ministry's report in 1994, 14,000 women became victims of sexual abuse. While the Human Rights Organization claims that the number of women sexually abused or raped is much more

6 Batool, 2007, Surayah Batool, Tadeed Tahreek-e-Niswan aur Islam, Lahore, 2007 Idara Munshuraat, pg: 34-35).

${ }^{7}$ Dr. Fazal Illahi, pg: 112

${ }^{8}$ Sahafat, Daily News Sahafat 28-Jan-1997 
The Prevalence of Sexual Abuse in Women (Types, Causes, Effects) and Its Remedies in Islam

but many of the sexually abused or raped women don't come forward. ${ }^{9}$ In 1992, the Serbian (racist Christains) oppressed Muslims of Bosnia and among those some 50 thousand women were sexually abused or raped. ${ }^{10}$ According to Human Rights Louis Committee 1995, a rescue team surveyed in Tanzania regarding refugees from Burandi and found out that out of 2930 women of Burandi between the age of 12-49, present at Kanemlwa Camp 26 percent of them were sexually abused or raped. ${ }^{11}$

\section{TYPES OF SEXUAL ABUSE:}

There are six major types of sexual abuse against women, one or the other type is often witnessed in every case of sexual abuse or rape, these are:

(a) Gang Rape/Sexual Abuse in Gang, (b) Sexual Abuse by Feud, (c) Rape or Sexual Abuse in imprisonment, (d) Politically motivated Sexual Abuse or Rape, (e) Sexual Abuse or Rape for pleasure and, (f) Sexual Abuse or Rape for Revenge.

(a) Gang Rape/Sexual Abuse in Gang: This type of sexual abuse is to be found from ancient times, from ancient times the conquering armies used to sexually abuse women of conquered nations. A fine was charged against Japanese Government for sexually abusing Philipinian women during Second World War. According to a report of National Women Studies, Muslim women of Pilestine have been sexually abused by Isaerli army after women of Kashmir and Bosnia, another report claims that 60,000

\footnotetext{
${ }^{9}$ Abdul Ghani Farooq pg: 111

${ }^{10}$ Khuram Murad, Magrid Aur Alam-e-Islam: Aik Mutalela, Lahore, 2006 Idara Munshuraat pg:153
}

${ }^{11}$ Ihsan Leghari, pg: 104 
The Prevalence of Sexual Abuse in Women (Types, Causes, Effects) and Its Remedies in Islam

women of Bosnia were sexually assaulted. ${ }^{12}$

(b) Sexual Abuse by Feud: We live in a feudal society, and we see some tyrant acts in such a society. The feudal lords, landlords and their assistants sexually abuse with women of their farmers and peasants, many of such cases are reported in newspapers, magazines and media. ${ }^{13}$

(c) Sexual Abuse in Imprisonment: In recent past a US based human rights organization Asia Watch has released a report regarding Pakistani women in jails and alleged that 70 percent of Pakistani women in jails have been sexually abused by cops. It also claimed that police is directly or indirectly involved in 12 out of 20 cases. (Tanveer, 2004, pg: 236). ${ }^{14}$

(d) Politically Motivated Sexual Abuse or Rape: This type of sexual abuse is witnessed to demoralize opposition, blackmailing the government or to create chaos for political opponents, most often women of political rivals are abducted and sexually abused. ${ }^{15}$

(e) Sexual Abuse or Rape for Pleasure: Since centuries sexual abuse for pleasure is present in our society, girls and women are trapped are told they would get married, women are also sexually abused on promise of being employed.

(f) Sexual Abuse or Rape for Revenge: In our society women become victim of every kind of revenge, as in Sindh woman is considered as

12 Tanveer, Tanveer Junejo, Aurat, Samaj Ain Dadh, Karachi, 2004 Aurat Zad Woman Research Publications pg: 234-235

${ }^{13}$ Tanveer Junejo, pg: 236).

14 Tanveer Junejo, pg: 236

15 Tanveer Junejo, pg: 237). 
The Prevalence of Sexual Abuse in Women (Types, Causes, Effects) and Its Remedies in Islam

symbol of honor and dignity, and to destroy the honor and dignity of opponents woman is victimized, such incidents are also witnessed in Punjab.

\section{TEACHINGS OF ISLAM AGAINST SEXUAL ABUSE:}

Islam considers sexual abuse as heinous sin, while adultery, sexual intercourse between two person even with consent but out of marriage law is also a sin according to Islam and the punishment for that according to Islamic is 100 lashes for unmarried persons, and death by stoning to married persons, four witnesses are require to prove this crime in Islam or the culprit confesses in the court of law, if anyone of the two confesses and the other denies it, in that case punishment would be given to the person confessing it. But if any woman accuses a man of raping or sexually abusing her, than after investigation the accused would be punished if found guilty. In the Hadud Ordinance of Pakistan there is no difference between sexual abuse or rape and sexual intercourse with consent. Both crimes are to be judged according to same criteria, meaning any woman accuses a man of rape or sexual abuse and is unable to provide evidence; in that case the victim would also be punished according to the Hudud Ordinance of Pakistan. ${ }^{16}$

Such an act in the name of Islam is tyranny and injustice, as the sharia, logic and reasoning demands a difference between victim and accused. If

${ }^{16}$ Zahid, , Muhammad Zahid Iqbal, Huḍooḍ Oriḍ̄inānce Men Ṭārmeem Ṭeḥfooz Ḥuqooq-e- Nị̄̂āan Bīll, Lahore, 2006, Kitab Dost Publisher pg: 78-79 
The Prevalence of Sexual Abuse in Women (Types, Causes, Effects) and Its Remedies in Islam

we look into Islamic law we find that it doesn't call the accuser as innocent. The Law of 'Qazaf' given by Almighty Allah is prove of that, this law is implemented on those who falsely accuse someone, while the victim is exempted from this law. If the victim doesn't have eye witnesses but some other evidences which prove the crime, then the criminal must be punished and the victim should be given justice, according to Islam four witnesses are required to testify sexual intercourse with consent, but for rape or sexual abuse four witnesses are not required, it could be testified from other sources getting help from science and technology, from DNA and other medical tests the crime and criminal could be identified.

Allama Abdul Qadir Auoda in his famous book 'Tashree-ul-Jinnai-ulIslami' writes that if any woman is raped or sexually abused she won't get any punishment, Allah Almighty says:

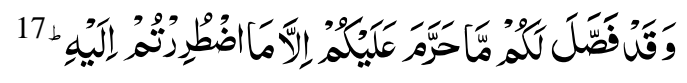

"When He hath explained to you in detail what is forbidden to you."

Allah has openly stated that if something compels you in time of need, than it is not unlawful to you.

Likewise Allah Almighty says:

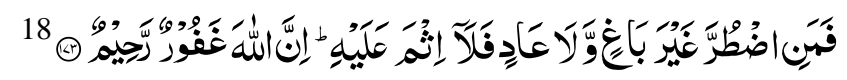

"But if one is forced by necessity, without willful disobedience, nor

\footnotetext{
${ }^{17}$ Al-Quran : ( 6) 119

${ }^{18}$ Al-Quran: (2) 173
} 
The Prevalence of Sexual Abuse in Women (Types, Causes, Effects) and Its Remedies in Islam

transgressing due limits, - then is he guiltless. For Allah is Oft-forgiving Most Merciful.

While according to a tradition of Prophet of Allah: My people would exempted from sins committed by mistake. So it some woman is forced for sexual intercourse, she won't be punished. ${ }^{19}$

In the time of Prophet of Allah one woman was forced for sexual activity and that woman indulged in the act helplessly, when that case came to Prophet of Allah, He didn't punished the woman as she was a victim of circumstances. $^{20}$

Likewise if someone has sexual intercourse with a woman after blackmailing her, even then she won't be punished. In the time of Hazrat Umar a woman asked a shepherd to give her milk, he in return asked for sexual favor, the woman helplessly indulged in sexual act, when that case reached Hazrat Umar's Court, he consulted Hazrat Ali, who replied the woman was helpless at that time, after which she wasn't punished and gave her compensation. ${ }^{21}$

${ }^{19}$ Audah, 1985, Abdul Qadir Audah, Ṭāṣhree-ūl-Jināāi āl-Īṣlāmī, Bāṣeerāt, DarulHaya, al-Taras, al-Arabia pg: 364).

${ }^{20}$ Āl Moṣoāṭ āl-Fīqāh, Kuwait, 1992 Ministry of Uqaf, vol: 24, pg: 31

${ }^{21}$ Sabiq, , Al-Sayed Sabiq Berut, 1995 Darul-Kitab al-Arabi, vol: 2, pg: 438 
The Scholar Islamic Academic Research Journal

Vol. 5, No. 2 || July -December 2019 || P. 128-138

https://doi.org/10.29370/siarj/issue9ar13

In the light of these two cases the experts of Fiqh claim that if a woman is forced or blackmailed to indulge in sexual act, she won't be punished, on the hand she would get help in favor.

\section{CONCLUSION:}

Sexual Abuse or rape is common violation of women' rights in our society and women are victims of it, as it is a common practice, there are six different types of sexual abuse, such as sexual abuse for pleasure, for revenge, sexual abuse in imprisonment, sexual abuse in feudal society, gang rapes, and politically motivated sexual abuse.

According to Islamic teachings, almost all the experts of Fiqh agree that if anyone tries to sexually abuse or rape a woman, he won't be punished under fornication law but he would get punishment of Harba. Famous Malki scholar Imam Abu Bakr bin Abdullah bin Al-Arabi in his book 'Ahkam-ul Quran' writes that the punishment of Harba is not only imposed upon loss of wealth and property but also on sexual abuse or rape. $^{22}$

It is clearly stated in Islamic law sexually abused or raped woman should get mercy, and if she is unable to present eye-witnesses, then other evidences with help of science and technology like DNA and other tests should be considered. ${ }^{23}$

\footnotetext{
${ }^{22}$ Ibne-Arabi, Mohammad bin Abdullah Abu Bakr, Āḥkāām-ūl-Qūrān, Research: Mohammad Ali Bajavi, Berut, Darul-Murkat vol: 2, pg: 597

${ }^{23}$ Zahid, 2006, Muhammad Zahid Iqbal, Hudood Oridinance Men Tarmeem
} 
The Scholar Islamic Academic Research Journal

Vol. 5, No. 2 || July -December 2019 || P. 128-138

https://doi.org/10.29370/siarj/issue9ar13

\section{SUGGESTIONS:}

The punishment and evidence for sexual intercourse with consent and sexual abuse or rape should be changed and differentiated in the Hudud Ordinance of Pakistan.

DNA and other medical tests should be taken as primary evidence in case of abduction and sexual abuse or rape of women.

The victim of sexual abuse or rape should be given mercy and the culprit should be given punishment of Harba.

\section{(9)(1) (@)}

This work is licensed under a Creative Commons Attribution-NonCommercial-ShareAlike 4.0 International (CC BY-NC-SA 4.0)

Tehfooz Huqooq-e- Niswan Bill, Lahore, 2006 Kitab Dost Publisher, pg: 80). 